RASĀYAN J. Chem.

Vol. 13 | No. 4 |2308-2312| October - December | 2020 ISSN: 0974-1496 | e-ISSN: 0976-0083 | CODEN: RJCABP

RJC http://www.rasayanjournal.com http://www.rasayanjournal.co.in

\title{
IDENTIFICATION OF ALLELOCHEMICAL COMPOUNDS FROM EACH PART OF Tetracera indica (L.) MERR
}

\author{
D. Guntoro", D.W. Rokhmaningsih and F.I. Nuryana \\ Department of Agronomy and Horticulture, Faculty of Agriculture, IPB University, Bogor, \\ 16680, (West Java) Indonesia, \\ *E-mail: dwi_guntoro@ipb.ac.id
}

\begin{abstract}
Plant allelochemical is very potential to be developed as an effective and environmentally friendly bioherbicide for controll weeds. Each part of Tetracera indica has potential as an allelochemical compounds bioherbicide. The purpose of this research was to identify the allelochemical content of each part of Tetracera indica (L.) Merr. Allelochemical compounds were analyzed using GC-MS (Gas Chromatography-Mass Spectrometer) method. The result of the analysis showed an extract of each part Tetracera indica had different type of compounds. Potential allelochemical bioherbicide compounds were fatty acids, flavonoids, and steroids. Flower extract has the highest compound of fatty acids and steroids compared to other parts.
\end{abstract}

Keywords: Allelopathy, Bioherbicide, Extract, GC-MS, Tetracera indica.

(C) RASĀYAN. All rights reserved

\section{INTRODUCTION}

The presence of weeds in agriculture can reduce plant growth and production caused by competition in the use of nutrients, light, and other growing facilities. One effort to save yield losses due to weeds is carried out weed control using synthetic herbicides. The use of synthetic herbicides is preferred because more efficient in terms of energy, time, and application costs compared to other techniques. The continuous use of synthetic herbicides causes several problems including concerns over the evolution of weed resistance, shifting weed species, water and soil surface pollution, and increased production costs. ${ }^{1}$

One alternative to overcome the adverse effects of using synthetic herbicides is replacing them with bioherbicides. Bioherbicides can be produced from plant extracts that have allelochemical compounds. Allelochemical compounds are produced by a plant to inhibit the growth of other plants in the vicinity. Allelochemical compounds can be developed in controlling weeds to reduce labor costs and increase efficiency without endangering the environment. ${ }^{2}$

Tetracera indica is the weed that has known its potential as a bioherbicide based on allelochemical compounds. The extract of T. Indica's canopy at a concentration of 50-250 g. . $^{-1}$ can suppress the growth of Ageratum conyzoides, Asystasia intrusa, and Eleusine indica. The compound chemical of $T$. Indica's canopy which is thought to play a role in suppressing weed is 1,2-benzenediol, chloroacetic acid, 2,6dimethoxy phenol, and pyrocatechol which are phenol group compounds. ${ }^{3}$

Allelochemical compounds are one type of secondary metabolites produced by plants. The distribution of some secondary metabolites is uneven in plant organs. ${ }^{4}$ This evidence from various research has been carried including research on phenol compounds in Cyperus rotundus, plant canopy extracts contain more phenol group compounds than rhizome extracts. ${ }^{5}$ Research on Clidemia hirta's allelopathic activity showed that leaf extract is the most significant compared to root extract and stem extract in inhibiting germination and growth of Raphanus sativus. ${ }^{6}$

Different concentrations and types of secondary metabolites may also be present in each part of T. indica. So far no research has been carried on this matter. All this time, $T$. indica has been used by Malay people in Malaysia, roots, and leaves used as medicine while the fruit is made of vinegar. The difference in the use of each part T. indica reinforces the suspicion of differences compounds in each part will affect its potential

Rasayan J. Chem., 13(4), 2308-2312(2020)

http://dx.doi.org/10.31788/ RJC.2020.1345763

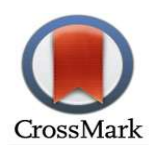


RASĀYAN J. Chem.

Vol. 13 | No. 4 |2308-2312| October - December | 2020

as a bioherbicide. The purpose of this research is to study the content of allelochemical compounds from each part of T.indica (L.) Merr. plant.

\section{EXPERIMENTAL}

Allelochemical compound analysis was performed using GC-MS (Gas Chromatography-Mass Spectrometer) method. Fresh Tetracera indica used to extract material are plants that have entered the generative phase taken from Cikabayan oil palm plantations which are located at an altitude of 206 meters above sea level with latosol soil type and high precipitation. Parts of the plants that were used in this research were leaves, stems, flowers, and roots. Leaves and flowers dried and then blended with a blender. The roots and stems chopped and then dried using an oven at $58^{\circ} \mathrm{C}$ for 15 hours, then mashed using a hammermill and disk mill. Making $T$. indica extract was carried using the maceration-distillation method with methanol as a solvent. The maceration method that is $1 \mathrm{~kg}$ of material soaked in 31 of methanol for 24 hours, after it was filtered, the remaining pulp was macerated up to 4 times. $^{7}$ The macerate was concentrated using a rotary evaporator so that an extract of each part of $T$. indica.

\section{RESULTS AND DISCUSSION}

Results of GC-MS (Gas Chromatography-Mass Spectrometer) analysis showed that were various types of compounds scattered in each section with different compositions and percentages in each part Tetracera indica. Compounds 9, 12-Octadecadienoic acid (Z, Z), Flavone 5,7-dihydroxy-8-methoxy (wogonin), and Hexadecanoic acid are three compounds with the largest content and are contained in all parts of $T$. indica. The compound with the highest percent area in all parts of $T$. indica is 9,12 -Octadecadienoic acid $(\mathrm{Z}, \mathrm{Z})$ which is a class of fatty acids.

Methanol extract $T$. indica compounds belong to a class of fatty acid, flavonoid, and steroid compounds. ${ }^{8}$ The leaves contain 11 compounds with 4 compounds classified as fatty acids (total $\%$ area: $55.53 \%$ ), 1 flavonoid (24.82\%), and 3 steroids (6.34\%) (Table-1). T. indica leaves were identified to contain flavonoid compounds, 5,7-dihydroxyflavone-O-8-sulphate, techtochrysin, wogonin, norwogonin, kaempferol, and quercetin. ${ }^{9}$ The results of this research indicate that flavonoid compounds identified in the leaves $T$. indica are only wogonin (Flavone, 5,7-dihydroxy-8-methoxy).

T. indica stem contains 12 compounds with 4 fatty acids (53.17\%), 1 flavonoid (24.01\%), and 2 steroids (4.15\%) (Table-2). According to previous research on the stem contain four monoflavonoids namely wogonin, norwogonin, quercetin, and techtochrysin ${ }^{10}$, and contain betulinic acid ${ }^{11}$, of the five compounds the only wogonin was identified in this research.

Table-1: The Compound identified in the T. indica Leaf Extract

\begin{tabular}{l|l|l|l|c|c}
\hline No. & \multicolumn{1}{|c|}{ Compound } & $\begin{array}{l}\text { Chemical } \\
\text { Formula }\end{array}$ & Class & $\begin{array}{c}\text { Percent } \\
\text { Area }\end{array}$ & $\begin{array}{c}\text { Retentio } \\
\text { n Time }\end{array}$ \\
\hline 1 & $9,12-$-Octadecadienoic acid (Z,Z) & $\mathrm{C}_{18} \mathrm{H}_{32} \mathrm{O}_{2}$ & Fatty acid & 38.88 & 30.054 \\
\hline 2 & Flavone, 5,7-dihydroxy-8-methoxy & $\mathrm{C}_{16} \mathrm{H}_{12} \mathrm{O}_{5}$ & Flavonoids & 24.82 & 33.123 \\
\hline 3 & Hexadecanoic acid & $\mathrm{C}_{16} \mathrm{H}_{32} \mathrm{O}_{2}$ & Fatty acid & 12.56 & 28.896 \\
\hline 4 & Stigmastan-3,5-diene & $\mathrm{C}_{29} \mathrm{H}_{48}$ & Steroids & 3.25 & 36.074 \\
\hline 5 & $9,12-O c t a d e c a d i e n-1-o l$ & $\mathrm{C}_{18} \mathrm{H}_{34} \mathrm{O}$ & Fatty acid & 2.97 & 32.544 \\
\hline 6 & $\begin{array}{l}\text { 2-Furancarboxaldehyde,5- } \\
\text { (Hydroxymethyl) }\end{array}$ & $\mathrm{C}_{6} \mathrm{H}_{6} \mathrm{O}_{3}$ & $\begin{array}{l}\text { Furan compounds, } \\
\text { aldehydes }\end{array}$ & 2.71 & 9.837 \\
\hline 7 & beta-Monoolein & $\mathrm{C}_{21} \mathrm{H}_{40} \mathrm{O}_{4}$ & Monoglyceride & 1.84 & 31.337 \\
\hline 8 & Stigmast-5-en-3-ol & $\mathrm{C}_{29} \mathrm{H}_{50} \mathrm{O}$ & Steroids & 1.74 & 39.370 \\
\hline 9 & Phytol & $\mathrm{C}_{20} \mathrm{H}_{40} \mathrm{O}$ & Diterpenoid alcohol & 1.37 & 29.599 \\
\hline 10 & Cholesta-3,5-Diene & $\mathrm{C}_{27} \mathrm{H}_{44}$ & Steroids & 1.35 & 35.060 \\
\hline 11 & Cis-13-Octadecenoic acid, methyl ester & $\mathrm{C}_{19} \mathrm{H}_{36} \mathrm{O}_{2}$ & Fatty acid & 1.12 & 29.489 \\
\hline
\end{tabular}

Table-2: The compound identified in the T. indica stem extract

\begin{tabular}{l|l|l|l|c|c}
\hline No. & \multicolumn{1}{|c|}{ Compound } & $\begin{array}{l}\text { Chemical } \\
\text { Formula }\end{array}$ & Class & $\begin{array}{c}\text { Percent } \\
\text { Area }\end{array}$ & $\begin{array}{c}\text { Retention } \\
\text { Time }\end{array}$ \\
\hline 1 & 9,12 -Octadecadienoic acid (Z,Z) & $\mathrm{C}_{18} \mathrm{H}_{32} \mathrm{O}_{2}$ & Fatty acid & 36.47 & 30.027 \\
\hline 2 & Flavone, 5,7-dihydroxy-8-methoxy & $\mathrm{C}_{16} \mathrm{H}_{12} \mathrm{O}_{5}$ & Flavonoids & 24.01 & 33.116 \\
\hline
\end{tabular}


RASĀYAN J. Chem.

Vol. 13 | No. 4 |2308-2312| October - December | 2020

\begin{tabular}{l|l|l|l|c|c}
\hline 3 & Hexadecanoic acid & $\mathrm{C}_{16} \mathrm{H}_{32} \mathrm{O}_{2}$ & Fatty acid & 13.94 & 28.889 \\
\hline 4 & $\begin{array}{l}\text { 2-Furancarboxaldehyde,5- } \\
\text { (Hydroxymethyl) }\end{array}$ & $\mathrm{C}_{6} \mathrm{H}_{6} \mathrm{O}_{3}$ & $\begin{array}{l}\text { Furan compounds, } \\
\text { aldehydes }\end{array}$ & 4.15 & 9.982 \\
\hline 5 & Stigmast-5-en-3-ol & $\mathrm{C}_{29} \mathrm{H}_{50} \mathrm{O}$ & Steroids & 2.58 & 39.432 \\
\hline 6 & 9-Octadecenoic acid (Z), methyl ester & $\mathrm{C}_{19} \mathrm{H}_{36} \mathrm{O}_{2}$ & Fatty acid & 1.73 & 29.496 \\
\hline 7 & $\begin{array}{l}\text { 4H-Pyran-4-on, 2,3-dihydro-3,5- } \\
\text { dihydroxy-6-methyl }\end{array}$ & $\mathrm{C}_{6} \mathrm{H}_{8} \mathrm{O}_{4}$ & Pyrone & 1.61 & 6.955 \\
\hline 8 & Cholest-5-en-3-yl-chloridocarbonate & $\mathrm{C}_{28} \mathrm{H}_{45} \mathrm{ClO}_{2}$ & Steroids & 1.57 & 35.067 \\
\hline 9 & $\begin{array}{l}\text { 2,3-Hydro-3,3-Dimethyl-2- } \\
\text { Methylenbenzofuran }\end{array}$ & $\mathrm{C}_{10} \mathrm{H}_{10} \mathrm{O}_{2}$ & & 1.28 & 34.619 \\
\hline 10 & beta-Monoolein & $\mathrm{C}_{21} \mathrm{H}_{40} \mathrm{O}_{4}$ & Monoglyceride & 1.15 & 31.337 \\
\hline 11 & 2-Hydroxycyclo pentadecanone & $\mathrm{C}_{15} \mathrm{H}_{28} \mathrm{O}_{2}$ & Ketone & 1.07 & 32.537 \\
\hline 12 & 13-Tetradecenal & $\mathrm{C}_{14} \mathrm{H}_{26} \mathrm{O}$ & Fatty acid & 1.03 & 32.330 \\
\hline
\end{tabular}

$T$. indica root contains the most types of compounds, namely 14 compounds. Compounds that belong to the allelochemical group are also more diverse, namely 4 fatty acid compounds (58.65\%), 2 flavonoids $(12.51 \%)$, and 4 steroids $(7.03 \%)$. The root has a flavonoid content with a lower percent area than leaves and stems but a higher steroid compound (Table-3).

Table 4 showed the compounds identified in flowers and fruit, there are 10 compounds, 4 compounds including fatty acid (61.43\%), 1 flavonoid compound (19.76\%), and 4 steroid compounds $(9.14 \%)$. The flower and fruit parts contain fatty acids and steroids with a higher percentage of the area than the other parts.

Visible differences in percent area of each class compounds including allelochemicals in each part T. indica. Percent area of compounds including allelochemical group is high in each part, but the high content does not automatically reflect $T$. indica can be used as a bioherbicide, because even though many compounds are identified including allelochemical groups, not every compound has allelopathic activity and only a small percent is true containing allelochemicals. ${ }^{12}$ Identification of compounds including allelochemicals requires further research.

Table-3: The Compound identified in the T. indica Root Extract

\begin{tabular}{|c|c|c|c|c|c|}
\hline No. & Compound & $\begin{array}{l}\text { Chemical } \\
\text { Formula }\end{array}$ & Class & $\begin{array}{l}\text { Percent } \\
\text { Area }\end{array}$ & $\begin{array}{l}\text { Retention } \\
\text { Time }\end{array}$ \\
\hline 1 & 9, 12-Octadecadienoic acid $(\mathrm{Z}, \mathrm{Z})$ & $\mathrm{C}_{18} \mathrm{H}_{32} \mathrm{O}_{2}$ & Fatty acid & 39.46 & 30.055 \\
\hline 2 & Hexadecanoic acid & $\mathrm{C}_{16} \mathrm{H}_{32} \mathrm{O}_{2}$ & Fatty acid & 15.26 & 28.903 \\
\hline 3 & Flavone, 5,7-dihydroxy-8-methoxy & $\mathrm{C}_{16} \mathrm{H}_{12} \mathrm{O}_{5}$ & Flavonoids & 9.45 & 32.999 \\
\hline 4 & $\begin{array}{l}\text { 2-Furancarboxaldehyde,5- } \\
\text { (Hydroxymethyl) }\end{array}$ & $\mathrm{C}_{6} \mathrm{H}_{6} \mathrm{O}_{3}$ & $\begin{array}{l}\text { Furan } \\
\text { compounds, } \\
\text { aldehydes }\end{array}$ & 7.38 & 10.217 \\
\hline 5 & \multicolumn{2}{|l|}{$\begin{array}{l}\text { Peri-Xanthnoxanthne-4,10-Dione, } \\
\text { 2-Acetyl-8-(1-Methylethyl) }\end{array}$} & & 4.87 & 36.115 \\
\hline 6 & Stigmast-5-en-3-ol & $\mathrm{C}_{29} \mathrm{H}_{50} \mathrm{O}$ & Steroids & 3.39 & 39.480 \\
\hline 7 & $\begin{array}{l}\text { 3,5-Dihydroxy-7-metoxy-2-(4- } \\
\text { Methoxyphenyl)-4H-Chromen-4-One }\end{array}$ & $\mathrm{C}_{17} \mathrm{H}_{14} \mathrm{O}_{6}$ & Flavonoids & 3.06 & 35.012 \\
\hline 8 & $\begin{array}{l}\text { 2,3-Dihydro-3,3-Dimethyl-2- } \\
\text { Methylenbenzofuran }\end{array}$ & $\mathrm{C}_{10} \mathrm{H}_{10} \mathrm{O}_{2}$ & & 2.7 & 34.633 \\
\hline 9 & 9-Octadecenoic acid (Z), methyl ester & $\mathrm{C}_{19} \mathrm{H}_{36} \mathrm{O}_{2}$ & Fatty acid & 1.98 & 29.496 \\
\hline 10 & 9,17-Octadecadienal, $(Z)-$ & $\mathrm{C}_{18} \mathrm{H}_{32} \mathrm{O}_{2}$ & Fatty acid & 1.95 & 32.564 \\
\hline 11 & $\begin{array}{l}\text { 1,2-Benzenedicarboxylic acid, mono (2- } \\
\text { ethylhexyl) ester }\end{array}$ & $\mathrm{C}_{16} \mathrm{H}_{22} \mathrm{O}_{4}$ & $\begin{array}{l}\text { Carboxylic } \\
\text { acid }\end{array}$ & 1.63 & 31.696 \\
\hline 12 & 3-Bromocholest-5-ene & $\mathrm{C}_{27} \mathrm{H}_{45} \mathrm{Br}$ & Steroids & 1.35 & 35.074 \\
\hline 13 & Stigmasta-5,22-dien-3-ol, acetate, $(3 \beta)$ & $\mathrm{C}_{31} \mathrm{H}_{50} \mathrm{O}_{2}$ & Steroids & 1.15 & 35.398 \\
\hline 14 & Stigmastan-3,5-diene & $\mathrm{C}_{29} \mathrm{H}_{48}$ & Steroids & 1.14 & 35.647 \\
\hline
\end{tabular}


RASĀYAN J. Chem.

Vol. 13 | No. 4 |2308-2312| October - December | 2020

Table-4: The Compounds identified in T. indica Flower and Fruit Extracts

\begin{tabular}{l|l|l|l|c|c}
\hline No. & \multicolumn{1}{|c|}{ Compound } & $\begin{array}{l}\text { Chemical } \\
\text { Formula }\end{array}$ & Class & $\begin{array}{c}\text { Percent } \\
\text { Area }\end{array}$ & $\begin{array}{c}\text { Retention } \\
\text { Time }\end{array}$ \\
\hline 1 & 9, 12-Octadecadienoic acid (Z,Z) & $\mathrm{C}_{18} \mathrm{H}_{32} \mathrm{O}_{2}$ & Fatty acid & 43.49 & 29.985 \\
\hline 2 & Flavone, 5,7-dihydroxy-8-methoxy & $\mathrm{C}_{16} \mathrm{H}_{12} \mathrm{O}_{5}$ & Flavonoid & 19.76 & 32.992 \\
\hline 3 & Hexadecanoic acid & $\mathrm{C}_{16} \mathrm{H}_{32} \mathrm{O}_{2}$ & Fatty acid & 14.67 & 28.834 \\
\hline 4 & Stigmastan-3,5-diene & $\mathrm{C}_{29} \mathrm{H}_{48}$ & Steroids & 4.86 & 36.060 \\
\hline 5 & 9 -Octadecenoic acid (Z), methyl ester & $\mathrm{C}_{19} \mathrm{H}_{36} \mathrm{O}_{2}$ & Fatty acid & 1.98 & 29.489 \\
\hline 6 & Cholest-5-en-3-yl-chloridocarbonate & $\mathrm{C}_{28} \mathrm{H}_{45} \mathrm{ClO}_{2}$ & Steroids & 1.83 & 35.047 \\
\hline 7 & gamma-Sitosterol & $\mathrm{C}_{29} \mathrm{H}_{50} \mathrm{O}$ & Steroids & 1.42 & 39.335 \\
\hline 8 & beta-Monoolein & $\mathrm{C}_{21} \mathrm{H}_{40} \mathrm{O}_{4}$ & Monoglyceride & 1.38 & 31.330 \\
\hline 9 & $9,17-O c t a d e c a d i e n a l,(Z)-$ & $\mathrm{C}_{18} \mathrm{H}_{32} \mathrm{O}_{2}$ & Fatty acid & 1.29 & 32.323 \\
\hline 10 & Ergost-5,8 (14)-dien-3-ol & $\mathrm{C}_{28} \mathrm{H}_{46} \mathrm{O}$ & Steroids & 1.03 & 34.598 \\
\hline
\end{tabular}

Compounds that are thought to be allelochemicals are Stigmastan-3,5-diene, Stigmast-5-en-3-ol, Stigmasta5,22-dien-3-ol, acetate, (3ß), Cholesta-3,5-Diene, and Cholest-5-en-3-yl-chloridocarbonate. Stigmastan compounds are compounds that potentially inhibit the germination of Mimosa pigra ${ }^{13}$ and Raphanus sativus. ${ }^{14}$ Cholesta compound is one of the allelochemical candidates in rice because its inhibitory activity is greater than other compounds. ${ }^{15}$ In addition to stigmastan and cholesta compounds, Phytol compounds have also been known to be active compounds in Terminalia catappa's leaves that can inhibit the germination and growth of Cleome rutidosperma. ${ }^{16}$

Identification $T$. indica in this research also showed the content of flavonoid compounds, wogonin, which was identified in all parts of $T$. indica with fairly high content. Flavonoids are known to have a role inhibiting growth which acts as a strong inhibitor of IAA-oxidase, but so far no research on the activity wogonin as an allelochemical. ${ }^{17}$ Research ${ }^{7}$ about wogonin compounds are known to have potential as diabetes mellitus drugs. ${ }^{11}$ Nanoparticle have the potential to be used with active compound in biomedical applications. ${ }^{18}$

Presence of 1,2-benzenediol, Chloroacetic acid, Phenol, 2,6-dimethoxy, and Pyrocatechol which are allelopathic compounds, but in this research, the analysis did not show the existence of compounds ${ }^{3}$. This might be due to differences in the solvents used, the research uses distilled water while this research uses methanol as a solvent ${ }^{3}$. Different solvents produce different compounds in their solutions such as cyperene and culmorin which are allelopathic compounds in C. rotundus can only be identified in fresh C. rotundus dissolved in water and not found in formulas dissolved in ethanol. ${ }^{19}$ Other factors that might cause differences in the results of the analysis are environmental factors that affect the production of $T$. indica allelochemical, namely state of population differences, life cycle and time of planting, soil and climate, and the presence of biotic and abiotic stresses. ${ }^{20} T$. indica used are taken during high rainfall so that it may cause quantity and quality of produced allelochemicals to be low because allelopathic compounds will be produced more in nutrient stress and drought. ${ }^{7}$

\section{CONCLUSION}

Extract from each part of Tetracera indica has different type and content of compounds. Potential compounds as bioherbicides are fatty acids, flavonoids, and steroids which are classified as allelochemical compounds. Flower extract has the highest compound fatty acids and steroids compared to other parts.

Purification of each compound indicated as allelochemical and testing of ability as bioherbicide needed to ascertain the compound allelochemical in T. indica.

\section{REFERENCES}

1. L.M. Juliano, M.C. Casimero, and R. Lewellyn, International Journal Pest Management, 56(4), 299(2010), DOI: 10.1080/09670874.2010.495795

2. H. Sodaeizadeh, and Z. Hosseini, In International Conference on Applied Life Sciences (ICALS2012), Turkey (2012), DOI:10.1007/978-1-4939-1019-9_3

3. B. Pramahdiyan, Thesis, Faculty of Agriculture, IPB University, Bogor (2017).

4. H. Nugroho, Thesis, Faculty of Biology, Gadjah Mada University, Yogyakarta (2014). 
RASĀYAN J. Chem.

Vol. 13 | No. 4 |2308-2312| October - December | 2020

5. A.V.C. Kusuma, M.A. Chozin, and D. Guntoro, Jurnal Agronomi Indonesia, 45(1), 100(2017), DOI:10.24831/jai.v45i1.11842

6. L. Ismaini, A. Lestari, Potential of Clidemia hirta as a bioherbicide, in: D.S. Ahmad, Sugiyarto, P. Ari, E.H. Udhi, Sutomo, Widiastuti, M.R. Saleh, S. Ichsan, and R. Dian (Eds), In Proceedings of the National Seminar on the Indonesian Biodiversity Society, Bandung (2015).

7. Q.U. Ahmed, B.B.S. Dogarai1, M.Z.A.M. Amiroudine, M. Taher, J. Latip, A. Umar and B.Y. Muhammad, Journal of Medicinal Plants Research, 6(49), 5912(2012), DOI:10.1007/978-981-287077-3 71

8. R. Saxena, R.S. Tomar, and M. Kumar, International Journal of Current Research in Biosciences and Plant Biology, 3(4), 43(2016), DOI:10.20546/ijcrbp.2016.304.008

9. A.M. Alhassan, Q.U. Ahmed, J. Latip, and S.A.A Shah, Natural Product Research, 33(1), 1(2019).

10. F. Abdullah, N.H. Ismail, F. Jamaludin, and S.N.A.M. Hashim, In The Open Conference Proceeding Journal, 4, 93(2013).

11. M.M. Hasan, Q.U. Ahmed, S.Z.M. Soad, J. Latip, M. Taher, T. M. F. Syafiq, M. N. Sarian, A.M. Alhassan, and Z.A. Zakaria, BMC Complementary and Alternative Medicine, 17(1), 431(2017).

12. E.L. Rice, Allelopathy, 2nd ed., Academic Press, Orlando, (1984).

13. W. Chavasiri, W. Prukchareon, P. Sawasdee, and S. Zungsotiporn, In Proceedings on World Congress on Allelopathy, Australia, pp. 21-26 (2005).

14. I.M. Chung, M. Ali, T.D. Khanh, M.G. Choung, H.J. Park, and A. Ahmad, Hindawi Journal of Chemistry, 27, 1(2013), DOI:10.1155/2013/505407

15. K.W. Kim, and K.U. Kim, Searching for rice allelochemicals, in: K.U. Kim, and D.H. Shin (Eds), Rice allelopathy, Kyungpook National University, Korea (2000).

16. A.A. Gani, Mukarlina and E. Rusmiyanto, Jurnal Protobiont, 6(2), 22(2017).

17. D.V. Riskitavani, and K.I. Purwani, Jurnal Sains dan Seni ITS, 2(2), 59(2013), DOI:10.12962/j23373520.v2i2.3593

18. N. Willian, Syukri, Zulhadjri, A. Labanni, and S. Arief, Rasayan Journal of Chemistry, 13(3), 1478(2020), DOI: $10.31788 /$ RJC.2020.1335760

19. M.A. Chozin, Y. Delsi, R. Saputra, N. Syarif, S.A. Arifin, and S. Zaman, In Proceeding 24th AsianPacific Weed Science Society for The Role of Weed Science in Supporting Food Security by 2020, Bandung, pp. 22-25 (2013).

20. A. Junaedi, M.A. Chozin and K.H. Kim, Hayati, 13(2), 79(2006), DOI:10.4308/hjb.13.2.79

[RJC-5763/2020] 